\title{
Wojna Strzemińskiego
}

Luiza Nader 


\section{Wojna Strzemińskiego}

Luiza Nader

TEKSTY DRUGIE 2017, NR 4, S. 71-95

DOI: $10.18318 /$ td.2017.4.5

W

artykule tym przedstawię analizę wybranych cykli tzw. „rysunków wojennych” Władysława Strzemińskiego z lat 1939-1944. Odnosząc je do problematyki przedstawionej w Teorii widzenia, zapytam o wartość referencjalną, autobiograficzną oraz o funkcję tych rysunków. Zaproponuję kategorię neuroświadectwa, która - jak będę starała się wykazać, w odniesieniu do sztuk wizualnych tego okresu buduje interesujące perspektywy badawcze, mobilizując jednocześnie ramy historii i neuroestetyki.

Na tzw. „rysunki wojenne” Władysława Strzemińskiego składa się przynajmniej siedem cykli prac. Zajmę się tymi, które znajdują się w kolekcji Muzeum Sztuki w Łodzi. Dużą ich część Strzemiński przekazał osobiście w listopadzie $1945 \mathrm{roku}^{1}$. Literatura na temat

* Serdecznie dziękuję prof. dr hab. Ewie Domańskiej oraz prof. dr. hab. Jackowi Leociakowi za cenne komentarze do niniejszego artykułu.

1 Część rysunków znajduje się w Muzeum Sztuki w Łodzi, część w Mu-

Luiza Nader adiunkt na Wydziale Zarządzania Kulturą Wizualną Akademii Sztuk Pięknych w Warszawie. Jej badania koncentrują się na sztuce nowoczesnej, awangardowej i neoawangardowej, związkach wydarzeń granicznych z polem kulturowym, na relacjach sztuki i Holokaustu. Inspiruje się teoriami afektu, traumy, pamięci, archiwum, koncepcjami związanymi z "materialnym zwrotem" oraz humanistyką i etyką afirmatywną. 
wspomnianych dzieł jest ograniczona. Jako pierwszy odniósł się do nich w krótkim fragmencie Julian Przyboś w 1956 roku, zauważając swoiste zawieszenie rysunków między abstrakcją a realizmem, ich syntetyczność, wyrazistą ekspresję, a zarazem skupienie na konkrecie. Część z nich interpretował poeta w kontekście tematyki związanej z Zagładą․ Kilkadziesiąt lat później, pod koniec lat 8o., Janina Ładnowska przenikliwie zwracała uwagę na emocjonalną zawartość prac wojennych oraz istotne znaczenie emocji w pismach Strzemińskiego, badając rysunki przede wszystkim w kontekście artykułu artysty z 1936 roku, Aspekty rzeczywistości, poświęconego m.in. krytycznej lekturze surrealizmu. Także przyjaciel twórcy Stefan Krygier akcentował rolę odczucia (oprócz formy i widzenia) oraz wrażliwości na cierpienie innych, czego, jego zdaniem, rysunki były wyrazem ${ }^{3}$. Ładnowska intepretowała prace te jako reakcję na „okropności wojny”, „dramatyczny wyraz losów nie jednostki, lecz wspólnych ludziom jako gatunkowi”", ich syntezy upatrując w powojennym cyklu kolaży Moim przyjaciołom Żydom. Krygier w podobnym duchu podkreślał obecne w rysunkach uniwersalne doświadczenie wojennej ludzkiej tragedii. Uwypuklał znaczenie tytułu dla interpretacji i łączył prace te, w tym aspekcie, przede wszystkich z surrealizmem. Z kolei, Andrzej Turowski jako pierwszy i do tej pory jedyny badacz zinterpretował i dowartościował wspomniane prace we fragmencie rozdziału Wojna, wchodzącego w skład syntetycznego ujęcia awangardowej i nowoczesnej historii sztuki w Polsce Budowniczowie świata. W rysunkach zauważał obecność doświadczenia biograficznego, a zarazem łączył je (podobnie jak Ładnowska) z cyklem Moim przyjaciołom Żydom, analizując wspomniane

sygnowane i datowane. Korpus prac, w tym tzw. rysunki wojenne artysta podarował Muzeum Sztuki w Łodzi w listopadzie 1945 roku, m.in.: Białoruś Zachodnia, Deportacje, Wojna domom (w księdze inwentarzowej jako: Wojna domowa), Twarze, Pejzaże i martwe natury, Tanie jak błoto, Ręce, które nie z nami.

J. Przyboś Przedmowa. Nowatorstwo Władysława Strzemińskiego, w: W. Strzemiński Teoria widzenia, Wydawnictwo Literackie, Kraków 1974, s. 8 (pierwsze wydanie w 1957 roku). Pierwszy raz jednak tekst ten ukazał się W "Przeglądzie Kulturalnym” 1956 nr 36 pod tytułem Władysław Strzemiński, przedrukowany w katalogu wystawy Katarzyna Kobro. Władysław Strzemiński, CBWA, Łódź 1956, Warszawa 1957 jako Nowatorstwo Władysława Strzemińskiego. W kolejnych wydaniach tekstów dokonano drobnych zmian.

3 J. Ładnowska Rysunki - realizm rytmu fizjologicznego, w: Władysław Strzemiński. In memoriam, red. J. Zagrodzki, Wyd. „Sztuka Polska”, Łódź 1988, s. 127-135; S. Krygier Władysław Strzemiński artysta, pedagog. Wspomnienia, w: Władysław Strzemiński. In memoriam, s. 40.

4 J. Ładnowska Rysunki - realizm rytmu fizjologicznego, s. 133. 
prace za pomocą takich pojęć jak ślad, cień, pustka ${ }^{5}$ Większość przywołanych autorów ${ }^{6}$, a także Zenobia Karnicka i Eleonora Jedlińska łączyli serię Deportacje z wysiedleniami ludności polskiej z Łodzi. Dość ogólnikowo, do „grozy wydarzeń Zagłady rozgrywającej się w Łodzi, w Polsce, w Europie [...] poza przedstawianą historią" odniosła cykl Tanie jak błoto ostatnia z wymienionych badaczek, bazując głównie na wspomnianym już tekście Turowskiego i książce Niki Strzemińskiej ${ }^{8}$. W powyższych artykułach dominuje ujęcie uniwersalizujące, przy czym zdecydowana większość autorów uważa przeżycia wojenne Strzemińskiego za kluczowe? . Natomiast Łukasz Kędziora wspomniane rysunki w kilku zdaniach omawia w swej książce poświęconej związkom sztuk wizualnych i neuroestetyki, nazywając artystę „świadomym

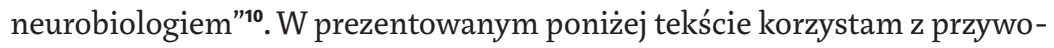
łanych analiz i interpretacji, splatam je, a zarazem proponuję ruch w nieco inną stronę. Biograficzne doświadczenie Strzemińskiego również uznaję

5 A. Turowski Budowniczowie świata.Z dziejów radykalnego modernizmu w sztuce polskiej, Universitas, Kraków 2000, s. 222, 225.

6 Z wyjątkiem Juliana Przybosia, który cykl Deportacje, Wojna domom (który określa jako Ruiny) oraz Tanie jak błoto sytuuje w kontekście Zagłady Żydów.

7 Z. Karnicka The life and work of Władysław Strzemiński - chronology, w: Władysław Strzemiński. On the 10oth anniversary of his birth, Muzeum Sztuki, Łódź 1994, s. 85; E. Jedlińska Cykle wojenne: rysunki i kolaże Władysława Strzemińskiego z lat 1939-1945. Doświadczenie wojny - żal i melancholia, w: Władysław Strzemiński. Uniwersalne oddziaływanie idei, red. G. Sztabiński, Akademia Sztuk Pięknych im. Władysława Strzemińskiego, Łódź 2005, s. 91-97. Pracą poświęconą rysunkom Strzemińskiego jest również niewielki katalog Warsztat Władysława Strzemińskiego, red. A. Wesołowska, Łódź 1985.

8 E. Jedlińska Cykle wojenne..., s. 94.

9 N. Strzemińska Sztuka, miłość i nienawiść. O Katarzynie Kobro i Władysławie Strzemińskim, Scholar, Warszawa 2001. Pierwsze fragmenty książki ukazywały się pod koniec lat 80. w czasopiśmie "Sztuka". Pierwsze wydanie (niepełne) miało miejsce w 1991 roku (wyd. Res Publica, Warszawa)

Łukasz Kędziora jest pierwszym badaczem, który w twórczości Strzemińskiego w sposób odkrywczy zauważył wątki neuroestetyczne. W swojej pracy magisterskiej poddał interesującej analizie z perspektywy neuroestetyki wybrane prace artysty z lat 30. i 40. XX wieku (całkowicie pomijając jednak rysunki wojenne), Moim przyjaciołom Żydom oraz Teorię widzenia, zob. Ł. Kędziora Neuroestetyka jako nowa metoda analizy obrazów, promotor: Piotr Piotrowski, Instytut Historii Sztuki, Wydział Historyczny UAM, Poznań 2012, s. 59-69. Kędziora słusznie nazywa Strzemińskiego w swej pracy ",!świadomym neurobiologiem", wskazuje również m.in. na "bodziec empatyzujący" w Moim przyjaciołom Żydom. W niniejszym tekście od wołuję się do książki Ł. Kędziory Wizualność dzieła sztuki: ocena potencjału neuroestetyki w badaniach historyczno-artystycznych, Wydawnictwo Naukowe Uniwersytetu Mikołaja Kopernika, Toruń 2016, s. 120. 
za punkt wyjścia dla powstania rysunków, jednak chciałabym je zobaczyć nie jako prace uniwersalizujące czy abstrahujące wojnę i Zagładę, lecz odwrotnie - jako bezpośrednią odpowiedź naocznego, czującego obserwatora, emocjonalnie, niemal cieleśnie zaangażowanego w wydarzające się sceny wywłaszczenia, cierpienia, okrucieństwa i śmierci w trzech bardzo różnych kontekstach: Białorusi Zachodniej, wcielonej do III Rzeszy Łodzi i Litzmannstadtghetto. Proponuję zatem lekturę rysunków wojennych Strzemińskiego jako neuroświadectwa.

\section{Pozycjonowanie}

Strzemiński podczas II wojny światowej nie był ofiarą. Być może najbliżej opisuje jego podmiotową pozycję kategoria obserwatora i pojęcia takie jak płynność, przechodniość i nieugruntowanie. 1 września 1939 roku, zapewne rozumiejąc realne zagrożenie rozstrzelania przez niemieckie Einsatzgruppen, wraz z żoną - Katarzyną Kobro, i kilkuletnią córką Niką Strzemiński przedostał się z Łodzi na Wschód Polski, do Wilejki Powiatowej. Nie jest jasne, jaką tożsamość narodową artysta przyjął w kolejnych miesiącach. Wiadomo jedynie, że jesienią/zimą 1939/1940 uczył w gimnazjum" ", zaprojektował również dekoracje powiatowego miasteczka uświetniające obchody 1 maja 1940 roku². To, że Strzemińscy przeżyli jesień/zimę 1939/1940 w Wilejce Powiatowej, a następnie w jednym $\mathrm{z}$ ostatnich transportów, w miarę bezpiecznie dojechali do Litzmannstadt, graniczy niemal z cudem. Czy możliwe jest, by artysta przyjął obywatelstwo radzieckie? A może (co bardziej prawdopodobne) decyzja o wyjeździe z Wilejki była próbą ucieczki przed obywatelstwem radzieckim i łączyła się z przybierającą na sile właśnie w pierwszej połowie 1940 roku akcją paszportyzacyjną na terenach wcielonej do ZSRR Białorusi Zachodniej? Komentarz na temat tego problemu znajduje się m.in. w dzienniku Katarzyny Kobro odnośnie do zimy 1939/1940 roku: „Strzemiński radził mi zapisać się jako Polka. Zapisałam się jako Rosjanka. Kiedy po Bożym Narodzeniu były wysiedlania, a za ścianą przeprowadzano rewizje, on błyskawicznie spalił moją metrykę urodzenia w Moskwie i akt ślubu ze Smoleńska"13.

11 Tamże, s. 81.

J. Przyboś Strzemiński przed śmierciq, w: Zapiski bez daty, Państwowy Instytut Wydawniczy, Warszawa 1970, s. 331. Przyboś wspomina o tym wydarzeniu na podstawie relacji Jerzego Putramenta.

K. Kobro, fragment dziennika, cyt. za N. Strzemińska Sztuka, miłość i nienawiść..., s. 81. 
W jaki sposób Strzemiński wraz z rodziną przeżył dwie wielkie deportacje $\mathrm{e}^{14}$ uderzające głównie w ludność polską (zarówno jako reprezentant polskiej inteligencji i jako uciekinier z Polski Centralnej)? Dlaczego miał szansę uczyć w szkole i dlaczego został dopuszczony do projektowania propagandowych dekoracji? Jeśli przyjął obywatelstwo radzieckie właśnie wtedy - bardziej zrozumiałe wydaje się późniejsze zapisanie się Strzemińskiego na listę rosyjską, jeśli nie - tym bardziej upokarzająca i wstydliwa musiała być dla niego ta decyzja. Być może w tym mało znanym wątku biografii obojga artystów między jesienią 1939 a wiosną 1940 roku na Białorusi Zachodniej, tkwi zarzewie późniejszego ostrego konfliktu między Kobro i Strzemińskim. Na pewno pytania dotyczące tożsamości (nie tylko) narodowej w tym okresie stały się sprawą decydującą o życiu bądź śmierci. Mniej więcej w połowie maja 1940 roku Strzemińscy powrócili do Łodzi, wtedy położonej już w Kraju Warty, podlegającej intensywnej germanizacji. By było to możliwe, jak pisze córka, jako argumentem artyści posłużyli się niemieckim pochodzeniem Katarzyny Kobro ${ }^{15}$. Był to jeden z ostatnich transportów, który trafił do Łodzi. Już w czerwcu 1940 roku uciekinierzy z Polski centralnej, którzy deklarowali chęć powrotu, zostali wywiezieni w głąb ZSRR ${ }^{16}$. Błędnie przeliterowane nazwisko z alfabetu rosyjskiego na łaciński (Strschemid[ń?]ski) uratowało Strzemińskiemu życie, przez całą wojnę artysta ukrywał się pod tą nieco przypadkową tożsamością ${ }^{17}$. Z tego też powodu prawdopodobnie Strzemińscy nie powrócili do swego mieszkania na ul. Srebrzyńskiej. W pierwszym okresie mieszkali u zaprzyjaźnionej rodziny Krauzów (Jerzy Krauze był volksdeutschem, dopomógł Katarzynie Kobro i jej siostrze Werze w uratowaniu przedwojennego dorobku Strzemińskiego), następnie wyprowadzili się na Karolew

14 Jak podaje Eugeniusz Mironowicz, do dwóch pierwszych deportacji na Zachodniej Białorusi, o których wspominam, doszło 10 lutego i 13 kwietnia 1940 roku, zob. E. Mironowicz Białoruś, Wydawnictwo Trio, Warszawa 2007, s. 168-169.

15 Tamże, s. 83.

16 T. Snyder Czarna ziemia. Holokaust jako ostrzeżenie, Znak Horyzont, Kraków 2015, s. 168. Małgorzata Ruchniewicz pisze, że deportacja ta dotyczyła uchodźców z Polski Centralnej i Zachodniej, którzy nie mieli radzieckiego paszportu. Decyzja o tej deportacji zapadła w marcu 1940 roku. M. Ruchniewicz Wieś zachodniobiałoruska 1944-1953: wybrane aspekty, Wydawnictwo Uniwersytetu Wrocławskiego, Wrocław 2010, s. 85.

17 Zob. dokument Strzemińskiego wydany w Litzmannstadt. Dziewiąta litera nazwiska podanego na dokumencie jest niejasna, można odczytać ją zarówno jako „d" lub „ń". Akta w sprawie Władysława Strzemińskiego, Prokuratura Sądu Specjalnego Karnego w Łodzi, Archiwum Państwowe w Łodzi, sygnatura R. 3087/45, 2013 (spis 1/81). 
(dzielnica Łodzi). Rok później w niemieckiej Łodzi twórczość Strzemińskiego oraz założona przez artystę Międzynarodowa Kolekcja Sztuki Nowoczesnej została uznana za przynależącą do „sztuki zdegenerowanej” i publicznie potępiona ${ }^{18}$. W lipcu 1941 roku Strzemiński/Strschemid[ń?]ski, podobnie jak Katarzyna Kobro, wpisał się na listę rosyjską, gwarantującą w Kraju Warty pewne przywileje ${ }^{19}$. Jego podmiotową pozycję charakteryzowała niestabilność i niepewność. Jako artysta awangardowy, którego antynazistowskie poglądy były przed wojną powszechnie znane, a zarazem spektakularny reprezentant "sztuki zdegenerowanej" i człowiek o wysokim stopniu niepełnosprawności, zdemaskowany łatwo mógł stać się ofiarą (i tak jak Karol Hiller zostać rozstrzelany). Natomiast podpisanie listy rosyjskiej stawiało artystę niebezpiecznie blisko oprawców. Pisana po wojnie powieść wskazuje na ostre wyczulenie Strzemińskiego na punkcie list narodowościowych i zmiany tożsamości narodowej czy nawet fiksację na tej kwestii, a zarazem na poczucie winy z tym związane ${ }^{20}$. Równocześnie, na co wskazują prace artysty z okresu wojny, Strzemiński wykazywał współczucie dla ofiar obserwowanych scen przemocy i zbrodni, np. ofiar deportacji we wschodniej części Polski, wysiedlanych w Łodzi Polaków oraz mordowanej ludności żydowskiej w łódzkim getcie. Jego rysunki podejmują zadanie dawania specyficznego świadectwa przemocy, niesprawiedliwości i zbrodni.

Podobnie jak opisywany przez Aleksandrę Ubertowską Kazimierz Wyka, Strzemiński był obserwatorem o niezwykle wąskim polu widzenia ${ }^{21}$. Najpierw w Wilejce Powiatowej, a następnie od maja 1940 roku do końca wojny w Litzmannstadt artysta był odcięty zarówno od informacji, jak i od swojego środowiska artystycznego. Żył jednak w przestrzeni empirycznych faktów: nieustannego zagrożenia, terroru, śmierci. Obserwował destrukcję państwowości w latach 1939-1940 na ziemiach okupowanych przez ZSRR, a następnie postępującą Zagładę Żydów w Litzmannstadtghetto. Rysunki Strzemińskiego, wykonywane równolegle wobec przekraczających fantazmaty faktów,

18 A. Kargel Internationale Kunst, "Litzmannstadter Zeitung” $1941 \mathrm{nr} 82$.

19 Zob. wspomniany dokument Strzemińskiego z Litzmannstadt, Akta w sprawie Władysława Strzemińskiego. W. Strzemiński Fragment powieści, w: Powidoki życia. Władysław Strzemiński i prawa dla sztuki, Muzeum Sztuki, Łódź 2012, s. 347-395.

21 A. Ubertowska „Tchnienie małostkowej nekrofilii”. Zagłada w eseistyce Kazimierza Wyki, w: tejże Holokaust. Auto(tanato)grafie, Wydawnictwo Instytutu Badań Literackich PAN, Warszawa 2014, s. 98 . 
ukazują destrukcję i bezprawie zarówno pod okupacją radziecką, jak i niemiecką, nie zrównując ich jednak.

Zagłada Żydów w wojennej twórczości Strzemińskiego nie ma miejsca centralnego. Wizualne notatki powstają niejako na marginesie, wzbierają jak fale, by zyskać rozpoznanie jako wydarzenie radykalnie przełamujące pojęcie historii, człowieczeństwa czy estetyki w powojennym już cyklu Moim przyjaciołom Żydom ${ }^{22}$ (1945-1947). Zanim do tego dojdzie, bliskość specyficznego doświadczenia Zagłady - nie przez ofiary, lecz przez obserwatorów Szoa zdaje się przezierać się w całej swej ambiwalencji właśnie przez niektóre cykle wojenne, przede wszystkim w pracach Tanie jak błoto (1943-1944). Ta marginalność, jak sądzę, ma jednak swoje znaczenie, podobnie jak w przypadku piśmiennictwa Kazimierza Wyki podsumowującego okres wojny, na co przenikliwie zwróciła uwagę Aleksandra Ubertowska. Badaczka określa strategię autora Życia na niby (w tym konkretnym przypadku eseju Dwie jesienie) jako „pozycjonowanie”: ,autor bardzo starannie opisuje pozycję w przestrzeni, z jakiej obserwował warszawskie powstanie, miał bowiem świadomość faktu, że ta pozycja określa również sąd o nim i stosunek [do niego]”23. Owa „pozycja w przestrzeni” zarówno w przypadku Wyki, jak i Strzemińskiego zakładała pewien dystans wobec opisywanych wydarzeń, rozumiany jednak nie jako wyraz obiektywizmu, ale świadomej autokrytyki własnego miejsca wobec rozgrywającego się okrucieństwa. Miejsca zawsze już uwikłanego w scenę rozgrywającej się zbrodni, pozbawionego niewinności i neutralności. W przypadku Wyki były to Krzeszowice, w przypadku Strzemińskiego - Wilejka Powiatowa, a następnie Litzmannstadt. Ubertowska określa eseje Wyki jako „autobiograficzną relację o doświadczeniu wojny i Zagłady"24. Podobnie widzę rysunki Strzemińskiego, z zachowaniem jednak specyfiki wizualnego medium rysunku. Artysta notował w swoim raporcie rysunkowym najpierw relację z Białorusi Zachodniej, potem z Litzmannstadt, zapisując represje wobec cywilnej polskiej ludności, a następnie odnosząc się do dokonującej się dosłownie na jego oczach, postępującej Zagłady Żydów

22 Pod tym tytułem cykl ten powszechnie znany jest w dostępnej literaturze. Jednak, jak sądzę, Strzemiński tytułował swój cykl nieco inaczej, Pamięci przyjaciół-Żydów. Więcej na ten temat zob. L. Nader Wunderblock Strzemińskiego. Pamięci przyjaciółŻydów, http://www.riha-journal. org/articles/2014/2014-oct-dec/special-issue-contemporary-art-and-memory-part-1/nader-strzeminski-pl (23.05.2017). 
w Litzmannstadtghetto. Te trzy wydarzenia w pewnym momencie zachodzą na siebie, przeplatają się, ale nie - przesłaniają. Niszczenie prawa, upadek rozumu, otwierająca się otchłań przemocy zdają się kulminować w rysunkach, których prawdopodobnym odniesieniem jest Zagłada Żydów, z marginesu wysuwająca się na wydarzenie centralne. Kazimierz Wyka mniej więcej w tym samym czasie napisał: „Formy, jakimi Niemcy likwidowali Żydów, spadają na ich sumienie. Reakcja na te formy spada jednak na nasze sumienie"25. Rysunki Strzemińskiego jako owa reakcja - stanowią ważny wkład w historię polskiego sumienia.

\section{Neuroświadectwo}

Rysunki wykonane zostały ołówkiem na grubym, miękkim papierze, za pomocą matryc z kalki technicznej. Jak twierdziła Janina Ładnowska, na kalce artysta wykonywał obrys formy, który potem odbijał na kartonie i obwodził konturem $^{26}$.W pracach tych Strzemiński odwoływał się do swoich artystycznych doświadczeń angażujących tzw. organiczną lub biologiczną linię, która pojawiła się na początku lat 30. w Pejzażach morskich, a następnie bardziej dosadnie, jak zauważają badacze, w cyklu litografii Łódź bez funkcjonalizmu $(1936)^{27}$. Strzemiński poświęcił również rysunkom wojennym krótki, ale niezwykle frapujący fragment w Teorii widzenia pisanej między rokiem 1945 a 1952:

Przystępując do tych prac (z których większość spalili hitlerowcy podczas okupacji), subiektywnie odczuwałem je jako realistyczne i empiryczne, wymagające znacznie większej obserwacji niż obrazy uważane za realistyczne.

"Szkice, czy raczej matryce prac, rysowane były na kalce technicznej, następnie artysta odciskał je na miękkim zazwyczaj papierze, po czym odcisk obwodził ołówkiem. Strzemiński opracował pewien określony alfabet czy «słownik» form. Czasami na jednym arkuszu kalki znajdują się, pochodzące z jednego czasu, formy-rysunki zastosowane w pracach odległych od siebie o kilka lat. Zdarzają się kombinacje form.. Niektóre formy dają się prześledzić w wielu rysunkach na przestrzeni kilku lat. Zastosowana metoda dała artyście możliwość niemal nieskończonej konfiguracji form. [...] Takie opracowanie warsztatu służyło autorowi do osiągnięcia maksymalnej syntezy formy, całości optycznie jednolitej, przy tym zmiennej". J. Ładnowska Rysunki - realizm rytmu fizjologicznego, s. 130 
Lecz przesąd, że realizm to wiek XVI - ciążył nade mną. Ciążyły również fałszywe teorie, że każde odejście od tego „realizmu” jest odejściem do deformacji i abstrakcji. Z teorii tych wynikało, że to, co wymagało dużego skupienia uwagi i skoncentrowanej, wielostronnej obserwacji - jest „deformacją", a to, co wynikało z obserwacji powierzchownej, było - realizmem. [...]

Dopiero sprawdzenie bazy wzrokowej, określenie składników świadomości wzrokowej - pozwoliły mi na dokładną ich lokalizację: są to prace wykonane w oparciu o metodę empiryczną i polegające na włączeniu do świadomości wzrokowej oddziaływania wewnętrznych rytmów fizjologicznych. Jest to więc impresjonizm (widzenie fizjologiczne) odmienny od impresjonizmu historycznego (takiego, jaki się ukształtował w historii) przez to, że został w nim uwzględniony nowy składnik świadomości wzrokowej (rytm fizjologiczny, którego impresjonizm na ogół nie uwzględniał). Impresjonizm historyczny rozwijał zagadnienia związane ze wzrokową zawartością samych rzucanych spojrzeń. Natomiast odbiór tych spojrzeń, sposób w jaki nasz organizm reaguje, przyjmuje te spojrzenia - pozostawał na ogół poza obrębem dociekań impresjonistów, mimo że stanowi jeden ze składników fizjologicznego procesu widzenia. $^{28}$

Co miał na myśli Strzemiński, pisząc o swych rysunkach jako „odbiorze spojrzeń"? Czy też rozwijając to pytanie - z jakim doświadczeniem cielesnym wiąże się „przyjmowanie spojrzenia” ofiary deportacji, głodu, okrucieństwa, człowieka w rozpaczy, skazanego na śmierć, bo właśnie do takich scen rysunki się odwołują? Z jakiego rodzaju „transakcją" wiąże się w przypadku Strzemińskiego wymiana spojrzeń między ofiarą przemocy i obserwatorem jej nieszczęść, upokorzeń, śmierci?

We wspomnianym powyżej cytacie z Teorii widzenia zwraca uwagę specyficznie rozumiana naoczność oraz wieloaspektowa, wytrwała obserwacja zawarta w rysunkowych relacjach Strzemińskiego („metoda empiryczna”). Drugi punkt, który wyłania się ze słów artysty, może być określony jako przydanie pracom z okresu wojny, wartości raportu z wewnętrznego odczucia, cielesnego poruszenia („oddziaływanie wewnętrznych rytmów fizjologicznych") połączonego z intensywną pracą myśli i wielostronną analizą obserwowanej rzeczywistości, które powoduje przekształcanie i komplikację form 
(„co wymagało dużego skupienia uwagi i skoncentrowanej, wielostronnej obserwacji - jest deformacją"). Rysunki zatem, są pewną wypadkową próby odwzorowania zobaczonych scen, a zarazem cielesnej, afektywnej reakcji na percypowane wydarzenia („odbiór [...] spojrzeń, sposób, w jaki nasz organizm reaguje..."). Chciałabym zatem wysunąć twierdzenie, że artysta odwołuje się w swoich cyklach nie do abstrakcyjnych wyobrażeń czy do zuniwersalizowanego doświadczenia wojny, ale do konkretnych wydarzeń, których był bezpośrednim obserwatorem lub o których miał wiedzę. Na określenie tego fenomenu obecnego w wojennych rysunkach Strzemińskiego chciałabym zaproponować pojęcie neuroświadectwa. Aleksandra Ubertowska podsumowuje najważniejsze konceptualizacje pojęcia świadectwa jako amalgamatu kilku aspektów: „1)uwarunkowanego etycznie nakazu referencjalnego, 2) silnie zaznaczonej sygnatury autorskiej/autobiograficznej, której przypisuje się walor autentyczności, wiarygodności, i 3) kategorii głosu, oralności jako modelu «źródłowego przekazu» (który może, ale nie musi przenikać do struktury tekstu pisanego)"29. Rysunki Strzemińskiego mają tak istotne dla świadectwa odniesienie referencjalne i autobiograficzne (o czym za chwilę), natomiast jako reprezentacje wizualne zamiast oralności włączają inny rodzaj prymarnego doświadczenia - zdolność mózgu do widzenia i wytwarzania obrazów. Wcielają dosłowność i naoczność w podwójnym sensie. Jako neuroświadectwo rysunki artysty jednoczą zapis zewnętrznych, często granicznych wydarzeń, neurofizjologicznych procesów widzenia i związaną z nimi wewnętrzną, wisceralną, emocjonalną odpowiedź na zatrzymane na siatkówce oka sceny. Rysunkowy zapis nie dotyczy zatem wyłącznie wzrokowej obserwacji i wieloaspektowego oglądu obserwowanych scen, podmiotów i przedmiotów, ale jednocześnie cieleśnie doświadczanego konkretnego wydarzenia i związanej z nim reakcji obserwatora. Reprezentacja staje się ekranem, na którym zapisuje się doświadczana rzeczywistość, ciało obserwującego (reakcje fizjologiczne), a zarazem jego świadoma, podświadoma i nieświadoma odpowiedź. U Strzemińskiego zatem nie tylko obserwujący uwikłany jest w obserwowane, ale również vice versa: pod wpływem obserwowanych scen, obserwator nieuchronnie podlega ryzykownemu otwarciu i nieustannej zmianie. Właśnie ten fenomen zapisany w rysunkach (które co ciekawe, w swej formie bliskie są pismu) określam mianem neuroświadectwa.

29 A. Ubertowska Pomiędzy torturq a "krajobrazem ruin". O "podmiocie po Auschwitz" w eseistyce Jeana Amery'ego, w: tejże Holokaust. Auto[tanato]grafie, s. 22. 


\section{Białoruś Zachodnia, 1939}

Cykl Białoruś Zachodnia z 1939 roku został wykonany ołówkiem na białym kartonie o kształcie horyzontalnego prostokąta o wymiarach $31 \mathrm{~cm} \times 38 \mathrm{~cm}$. Artysta posługuje się konturowym, syntetycznym rysunkiem, charakteryzującym się precyzyjnie prowadzoną, specyficznie wijącą się linią. Owa linia pełni kilka funkcji: pozwala na oddzielenie formy od tła, jak i ją w nim zanurza (to co wypełnia wszystkie formy - to właśnie aktywne tło ziarnistego papieru), określa objętość, odległość, buduje bazową perspektywę, nadaje kształtom ekspresję.

Rysunki tego cyklu określa (z jednym wyjątkiem) gruby, czarny kontur zaznaczony miękkim ołówkiem. Strzemiński reprezentuje lokalną ludność wiejską, czyli białoruskie chłopstwo. Figury kobiet i mężczyzn są duże, masywne, niezgrabne. W pracy Mężczyzna i kobieta postać chłopki podkreśla chustka na głowie, obszerna spódnica, nieproporcjonalnie wielkie buty. Mężczyzna ma wydatny nos, charakterystyczną czapkę, wysokie buty i wpuszczone w nie obszerne nogawki spodni. Ich otoczenie jest charakteryzowane za pomocą rozlanej podłużnie plamy - indeksu niegościnnego, błotnistego podwórka lub pola. Figury przestawione na innych pracach tego cyklu, np. w rysunku Postać kobieca również w pejzażu nie są zadomowione, ale raczej od niego uzależnione, posuwają się, brną w pustej, białej, jakby stawiającej opór przestrzeni. Za pomocą tych kilku zabiegów Strzemiński zdaje się przywoływać krajobraz wyjątkowo mroźnej zimy 1939/1940, kiedy to temperatury spadały poniżej 45 stopni.

Linia określa zarówno podmioty, przedmioty, jak i elementy krajobrazu. W rysunkach nakreślono silną zależność między człowiekiem i jego siedliskiem. Wykreślone nią autonomiczne kształty znajdują się wobec siebie w dużej bliskości, jakby przyciągając się. Domy przybierają miękkie, niepewne, ciastowate formy. Niektóre ukazane są jako puste, dopiero co pozostawione, jak na rysunku Wieś, w innym (Człowiek i pejzaż z domami) do domu powraca się z wysiłkiem. Trwa proces dezintegracji, roztapiania się zarówno ludzi, jak i rzeczy. Nawet drzewa się chwieją. Linia zrównuje swym organicznym biegiem zarówno ludzi, przedmioty, jak i przyrodę, (jej) tętno określa wszystkie elementy przedstawionego tu świata. Na jedynym rysunku Dwie postacie, w którym Strzemiński użył twardego ołówka, co daje efekt cienkiej, szarej linii - w centrum przedstawienia został nakreślony mężczyzna oraz towarzyszące mu z prawej strony małe dziecko. Głowy mężczyzny i dziecka ujęte są z profilu, ciała zaś na wprost. Pierwszy z nich wyciąga ku lewej stronie rękę, w geście prośby, żebraniny. Ich skomplikowane, wybrzuszające 
się kształty, jakby powoli ulatniające się z tła (szary kolor cienkiej linii) odbiegają od masywnych form ukazanych w innych pracach. Czy to zapis głodu i biedy?

Swoim rysunkom Strzemiński nadaje dość nieoczekiwany, bo nie-polonocentryczny tytuł Białoruś Zachodnia (Polacy mówili raczej o Kresach Wschodnich). Tereny te ogarnięte były po 17 września 1939 roku anarchią i przemocą. To do obrazowanych przez Strzemińskiego chłopów Armia Czerwona kierowała hasła wyzwolenia od „ucisku polskich panów, obszarników, kapitalistów" ${ }^{\prime 30}$, obiecując równocześnie wolność, równość i dobrobyt. Nowe władze szybko przystąpiły do przejmowania wielkiej własności należącej do dworów, nacjonalizacji fabryk, parcelacji ziemi, a także intensywnych aresztowań i wywózek. Wśród „wrogów ludu” znajdowali się przede wszystkim przedstawiciele polskiej administracji państwowej, polscy osadnicy i ziemianie, inteligencja, duchowni, a także bogaci chłopi ${ }^{31}$. Małgorzata Ruchniewicz zauważa, że

rozmiar represji radzieckich przedstawiony na tle ogólnej liczby mieszkańców ziem okupowanych pozornie wydaje się nie mieć charakteru masowego [...]. Jeśli jednak uwzględnimy strukturę narodowościową represjonowanych i liczby te odniesiemy do położenia konkretnych grup narodowościowych na tych terenach, można już stwierdzić, że poziom strat ludności polskiej był wysoki. [...] Okupacja radziecka 1939-1941 z pewnością osłabiła polskość na tych terenach niszcząc grupy związane z przedwojennym aparatem państwowym, dawną hierarchię społeczną (klasy historyczne typu ziemiaństwo), szeroko pojęte grupy przywódcze różnego szczebla (działacze społeczni i polityczni, inteligencja) oraz zastraszając resztę ludności, rozbijając tradycyjne więzi społeczne. ${ }^{32}$

Obrazowane przez Strzemińskiego białoruskie chłopstwo również szybko doświadczyło działań stalinowskiego aparatu terroru, a warunki jego skromnego bytowania mimo początkowej poprawy (reforma rolna) w ciągu kilku miesięcy dramatycznie się pogorszyły (z powodu obłożenia m.in. przymusowymi dostawami produktów rolnych w grudniu 1939 roku, a następnie

Cyt za. M. Ruchniewicz Wieś zachodniobiałoruska 1944-1953: wybrane aspekty, s. 63. 
przymusowych robót na rzecz państwa i kolektywizacji w 1940 roku) ${ }^{33}$. Jak zauważa Małgorzata Ruchniewicz, wszystkie aresztowania i deportacje w latach 1939-1941 mocno uderzały również i w tę grupę społecznąą4. W rysunkach Strzemińskiego lokalną ludność wiejską przedstawiono raczej w sposób groteskowy niż demoniczny, budzący nie lęk, ale rodzaj współczucia. Ukazana jest nędza, codzienna walka o byt, kruchość egzystencji. Mimo swojej mocnej budowy figury wydają się być sprowadzane do poziomu nagiego życia czy też (używając słów Kazimierza Wyki) „wegetatywnego trwania” oscylującego „pomiędzy kurną chałupą a cmentarzem”35. Figury są pojedyncze, zawieszone w przestrzeni, wyizolowane. Bieda, niepokój, degradacja dotykają w równy sposób ludzi, ich skromnego dobytku i przyrody. W cyklu rysunkowym Biatoruś Zachodnia zauważalny jest większy udział przerysowania dający efekt groteski. W kolejnych cyklach na plan pierwszy wysunie się biologiczność.

\section{Deportacje, 1940}

Nie znamy dokładnych, miesięcznych lub dziennych dat cyklu Deportacje, co w tym przypadku, a także cyklu Tanie jak błoto, jest szczególnie ważne. W porównaniu do prac wcześniejszych figury ludzkie są drobniejsze, wykonane zróżnicowanym, wykalkulowanym obrysem. Linia stanowiąca kontur jest w nich bardziej różnorodna zarówno od strony objętości (wykonywana raz twardym, innym razem miękkim ołówkiem, raz srebrno-grafitowa, raz czarna), jak i stopnia złożoności, co wpływa na ekspresję prac. Linia określa nie tylko perspektywę, ale również ruch, aktywność, w których znajdujemy przedstawione przez Strzemińskiego postaci, ale także ich „żywotność”. Jeden z rysunków zatytułowany Wyrzuceni wykonano twardym ołówkiem. Formy subtelnie odcinają się od tła, układając się w postać pospiesznie idącej kobiety (?) i towarzyszącego jej dziecka ukierunkowanych w prawą stronę. Tworzą zawikłany, niemal dekoracyjny, miękko układający się w swych fałdach i zagięciach kształt, pokrewny (choć bardziej złożony) rysunkowi Dwie postacie (cykl Białoruś Zachodnia). Przedstawieniu kobiety i dziecka towarzyszą umiejscowione obok i poniżej ich stóp mniejsze formy, jakby zagubione, oderwane,

M. Wierzbicki Polacy i Białorusini w zaborze sowieckim. Stosunki polsko-białoruskie na ziemiach północno-wschodnich II RP pod okupacją sowieckg 1939-1941, Fronda, Warszawa 2007, s. 360-363. na niby, s. 151. 
„wywłaszczone" z ciał postaci. W innych rysunkach został wykorzystany miękki ołówek, opisujący kształt mężczyzny mięsistą, grubą linią (Na bruku), której stopień skomplikowania jest jednak nieporównanie mniejszy, ale nadal nawiązuje do kształtów biologicznych, komórkowych. Na trzech z sześciu rysunków z kolekcji Muzeum Sztuki można rozpoznać dorosłą postać trzymającą za rękę drobną figurkę dziecka. Organiczna linia raz grubsza raz cieńsza, różnicuje płeć (m.in. przez swoją grubość czy bardziej dekoracyjny układ), ale też zwraca uwagę na kruchość ciał kobiet, mężczyzn i dzieci, umowność zamieszkującego je życia. W każdej chwili mogą otworzyć się i je wytracić.

Ten zespół rysunków odnosi się, jak sądzę, do dwóch typów deportacji, których Strzemiński był bezpośrednim obserwatorem ${ }^{36}$. Pierwszy to dramatyczne deportacje ludności na tzw. Kresach Wschodnich (w tym na Białorusi Zachodniej), miejscowej i napływowej w pierwszej połowie 1940 roku. Po inwazji Armii Czerwonej główny atak stalinowskiego aparatu terroru (aresztowania, egzekucje, wywózki) na tych ziemiach został przypuszczony na polskie instytucje i elity, następnie urzędników, ziemian, bogatych chłopów, Żydów i ludność białoruską ${ }^{37}$. Strzemińscy byli świadkami dwóch pierwszych wywózek (z czterech). Do pierwszej fali deportacji doszło 10 lutego 1940 roku uderzyła ona w reprezentantów polskiego aparatu państwowego - pracowników służby leśnej (wraz z rodzinami) oraz polskich osadników ${ }^{38}$. Deportacja objęła około 50224 osób, spowodowała największą ilość ofiar śmiertelnych. Kolejna fala wielkich deportacji to 13 kwietnia 1940 roku, również dotyczyła ona głównie Polaków. Wywożono wówczas rodziny uwięzionych i zesłanych do obozów przez NKWD (m.in. urzędników państwowych, wojskowych, ziemian, „kontr-rewolucjonistów”) i uchodźców z Polski centralnej, w tym polskich Żydów, łącznie około 29699 osób ${ }^{39}$.

Na rysunku Jedyny ślad przedstawiono grubą czarną linią ołówka dwie połączone ze sobą uściskiem rąk postaci, większą i zupełnie małą, ukazane tyłem, zmierzające ku lewej stronie przedstawienia. Wyglądają jak dorosły mężczyzna mocno trzymający za rękę dziecko, zlewający się z nim niemal

Cykl Deportacje z wysiedleniami Polaków z Łodzi wiążą wszyscy wspomniani na początku autorzy zob. przypis 1, z wyjątkiem Przybosia, który błędnie łączy Deportacje z Zagładą Żydów. O związku cyklu Deportacje z Białorusią Zachodnią wspomniała w rozmowie ze mną w październiku 2015 roku jedynie dr hab. Iwona Luba. Na temat ten nie znalazłam tekstu.

T. Snyder Czarna ziemia..., s. 168. 
w jeden kształt. W dolnej partii widocznych jest kilka amorficznych form jak odciski butów roztapiające się na śniegu. W bardziej metaforyczny sposób można rozpatrywać te figury jako bezbronnych ludzi bez żadnej nadziei, osamotnionych w swym nieszczęściu, skazanych na zatracenie, powiązanych jednak afektywną więzią. Rysunek ten jest być może jedynym wizualnym zapisem sylwetek, które Strzemiński wówczas widział, które majaczyły w dali. Jedyny ślad wydaje się odnosić do którejś z fal wymienionych deportacji, być może lutowej, najstraszniejszej. Jak pisze Jan Tomasz Gross, zabierano ludzi z ulicy, całe rodziny wysiedlano z domów, bez względu na wiek i stan zdrowia, w ciągu jednej nocy wyludniały się całe obszary miasteczek i wsi ${ }^{40}$. Ogromna liczba deportowanych, zwłaszcza dzieci, umierała podczas transportu z głodu i zimna. Mróz sięgał minus 50 stopni. Martwe ciała, przede wszystkim zamarzniętych dzieci, straże wyrzucały z wagonów wprost na śnieg. WWilejce Powiatowej znajdowała się stacja kolejowa, Strzemiński mógł być świadkiem podobnych scen zarówno w grudniu 1939 roku, jak i w lutym 1940. „Nadchodzi 10 luty, jest noc, godzina 1sza, słychać na ulicy krzyki, i cóż tam ujrzałem! cały sznur sań ciągnął się bez końca, na którym siedziały matki z dziećmi, dużymi, a nawet z takimi, które miały po kilka tygodni. Na jednym z sań ujrzałem kobietę z sześciorgiem dzieci, z których dwoje bliźniąt miało po dwa tygodnie. Te biedne dzieci, matka otuliła w koce i tak wiozła je do stacji. Lecz niestety, ku wielkiej rozpaczy matki, dzieci w drodze do Rosji zamarzły, a ponieważ nie było innej rady wyrzucono je przez okno. Widząc to N.K. W.D. z pogardliwym uśmiechem mówili: «miorznut Polskije sobaki»", relacjonuje autor jednego ze świadectw przytaczanych przez Grossa, który w chwili tego wydarzenia miał 12 lat ${ }^{41}$.

Postać na rysunku Patrząca kobieta ulokowana w centrum przedstawienia, ukierunkowana jest w prawo, wydaje się coś trzymać na rękach. Może to tobołek, może małe dziecko. Ujęta jest w pozycji wyczekiwania, napięcia, a jednocześnie prezentuje siebie oraz to, co trzyma w/na rękach. Przedstawienie może być obrazem matki z małym dzieckiem oczekującej na deportację. Może jednak nawiązywać do innej sceny - częstego obrazu w tym okresie: kobiet wystających godzinami wraz z dziećmi pod przepełnionymi więzieniami, by przekazać swoim bliskim paczkę z żywnością i bielizną, kobiet wypatrujących swych bliskich. WWilejce Powiatowej, w której mieszkał wówczas

\footnotetext{
40 Marian U/1928/powiat dziśnieński/PGC, 121, W: „W czterdziestym nas matko na Sibir zesłali...", oprac. J.T. Gross, I. Grudzińska-Gross, Znak, Kraków 2008, s. 193.

41 Relację (nieopisaną przypisem) cytuję za J.T. Grossem, tamże, s. 71.
} 
Strzemiński z rodziną, znajdowało się więzienie, w tym okresie przynajmniej pięciokrotnie przepełnione. Jan Tomasz Gross przytacza wstrząsające świadectwa, w których mowa o więzieniach na tym obszarze, na przełomie 1939/1940 roku² ${ }^{42}$ Jak zauważa, pod więzieniami przebywało się również po to, by wypatrzyć bliską osobę, czy jeszcze żyje, a zarazem dać znak życia (podczas śledztwa oprócz tortur grożono uwięzieniem lub wywiezieniem członków rodziny) ${ }^{43}$. Przed więzieniami wystawały godzinami głównie kobiety z dziećmi, usiłujące przekazać skazanym żywność.

Drugi typ deportacji odnosi się do Litzmannstadt. Deportacje łączyły się z intensywną akcją germanizacyjną i dotyczyły ludności polskiej w Łodzi. Następowały od początku grudnia 1939 do marca 1941 roku. Z rejencji łódzkiej wysiedlono 76599 Polaków ${ }^{44}$. Polacy byli przesiedlani tylko z małym pakunkiem do obozów przejściowych, a następnie po kilku miesiącach wywożeniu do Generalnej Guberni lub na roboty do Niemiec. Wysiedlenia Polaków z Łodzi znalazły swój dramatyczny opis m.in. we wspomnieniach Mariana Minicha ${ }^{45}$. Po powrocie do Łodzi w maju 1940 roku Strzemiński wraz z żoną i córką zamieszkali po pewnym czasie na Karolewie, ale jak można przypuszczać - nie jako Polacy, lecz Rosjanie o niemieckich korzeniach. Jak podaje Andrzej Rukowiecki, w nocy z 30 na 31 sierpnia 1940 roku z Karolewa wysiedlono kilkaset polskich rodzin, głównie robotników, ich kwatery przejęli Niemcy z krajów bałtyckich i Wołynia ${ }^{46}$. Strzemińscy mogli być świadkami tych wysiedleń. Czy zamieszkali w jednym z opuszczonych mieszkań? Z deportacjami w Łodzi korespondują dwie wersje rysunku Na bruku, a także Bruk i Wyrzuceni. W trzech pierwszych rysunkach widzimy postać ludzką rysowaną dosadną, czarną kreską (zapewne mężczyzny). Kamienie tytułowego bruku zaznaczono kilkoma amorficznymi plamami. Dominująca w przedstawieniu pustka oznacza nie tylko wyzucie z dóbr materialnych, opuszczenie, ale też symboliczną utratę i degradację. W rysunku Wyrzuceni przedstawiającym kobietę i dziecko formy są skłębione, jakby oddając emocję wzburzenia, rozpaczy, gniewu, która przynależy zarazem do reprezentowanej postaci, jak

Tamże, s. 51-57, relacja dot. warunków w więzieniu w Wilejce Powiatowej s. 52.

Tamże, s. 54-55.

A. Rukowiecki Łódź. 1939-1945. Kronika okupacji, Dom Wydawniczy Księży Młyn, Łódź 2012, s. 84.

A. Minich-Scholz Marian Minich pod wiatr, w: M. Minich Wspomnienia wojenne, Szalona galeria, Instytut Wydawniczy Książka i Prasa, Warszawa 2015.

A. Rukowiecki Łódź..., s. 69. 
i opisującego jej stan obserwatora. Wszystkie rysunki cyklu Deportacje oraz Białoruś Zachodnia cechuje pewien dystans, zaznaczona jest wyraźna odległość między obserwatorem a rejestrowanym wydarzeniem. Obserwator, choć emocjonalnie angażuje się w przedstawienie (okazuje sympatię, współczucie, empatię w oburzeniu i rozpaczy), pozostaje jednak na zewnątrz. Sytuacja ta zmienia się w cyklu Twarze ${ }^{47}$, które portretowane są w niemal intymnej bliskości, szczególnie zaś w czterech rysunkach cyklu Tanie jak błoto, w których obserwator i obserwowana scena literalnie stapiają się - w rysunkowym przedstawieniu.

\section{Tanie jak błoto, 1943-1944}

Rysunki cyklu Tanie jak błoto wykonane zostały na papierze o zdecydowanie ziarnistej fakturze. W zbiorze Muzeum Sztuki w Łodzi to czternaście rysunków, jednak trzy z nich, o specyficznym tytule Na okopy, zdają się należeć do oddzielnej serii lub ją ustanawiać, jako że odbiegają od pozostałych. Wszystkie są sygnowane i datowane. Podłoże jednego z nich, najwcześniejszego (bez tytułu, 1943, 41,8 × 29,7 cm), wykonanego twardym ołówkiem i najdelikatniejszym konturem, stanowi papier lekko wzbogacany. Wrażenie ziarnistości, wręcz zabrudzenia faktury jest większe. W tym rysunku, jedynym również o kształcie wertykalnego prostokąta, widzimy dwie trzymające się za ręce figury: większą i mniejszą, kobietę (wskazywałaby na to wysoka dekoracyjność formy) i dziecko. Usytuowani są w centrum przedstawienia, ukierunkowani lekko w prawo, kobieta opiekuńczo wychyla się ku dziecku, głowa dziecka uniesiona jest do góry, wpatrzona w twarz kobiety, nogi dziecka zlewają się ze sobą. Wydaje się, że jesteśmy świadkami sceny, w której dziecko o coś pyta. Może jednak jest inaczej - może i dziecko i matka (?) odwracają od czegoś głowy, zwracając się ku prawej stronie. Lewa strona, która zieje pustką, odgrywa w takiej interpretacji retoryczną rolę elipsy lub literalnej odległości, która oddziela postacie od przerażającej sceny. Figury narysowane wybrzuszającym się konturem przedstawione są w taki sposób, że nie mamy pewności, czy zbliżają się w kierunku widza, czy też oddalają. Towarzyszą im ekspresyjne grafitowe odciski palców, które jednak nie zachodzą na połączone mocnym uściskiem rąk, zmierzające w nieznanym kierunku figury. Użycie twardego ołówka powoduje wrażenie, jakby kształty zanikały za zabrudzeniami, w porównaniu do mocnych odcisków palców wydają się wiotkie, lekkie, delikatne. 
We wszystkich pracach tego cyklu organiczna linia opisuje złożone kształty rozlewającymi się fałdami i zagięciami. Tylko w tym cyklu niektóre formy przerywają się, otwierając na pustkę podłoża. Nie ma jednego stałego punktu perspektywicznego. Na czterech pracach znalazły się płaskie ślady zabrudzonych grafitem ołówka palców, prawdopodobnie Strzemińskiego. Trzy stanowią iteracje trzech innych (różnią się od siebie nałożeniem na powierzchnię odcisków palców), jeden można uznać za syntezę dwóch rysunków. Właśnie ten rysunek będę opisywała i analizowała.

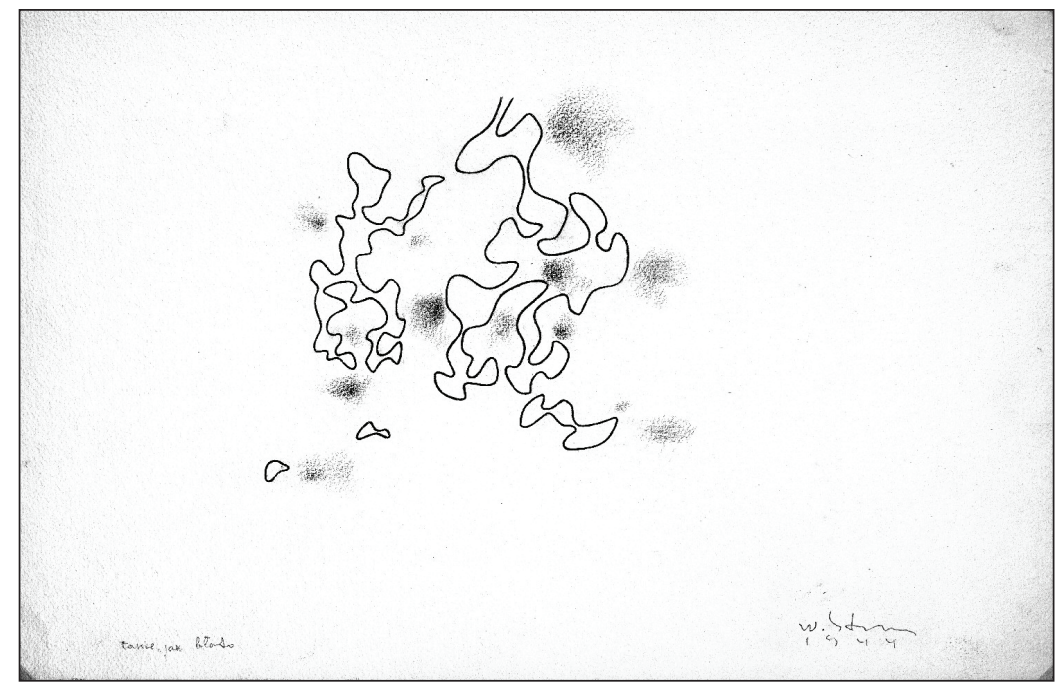

Władysław Strzemiński, Tanie jak błoto, z cyklu: Tanie jak błoto, ołówek, papier, 29,5×417, Muzeum Sztuki w Łodzi, (c) Ewa Sapka-Pawliczak - właściciel praw autorskich do dziełWładysława Strzemińskiego i Katarzyny Kobro.

Jako jedyny został nie tylko datowany i sygnowany (u dołu, po stronie prawej), ale również ręką artysty opatrzony odręcznym komentarzem/tytułem (u dołu, po stronie lewej): tanie jak błoto. Rysunek ten znajduje się od 1974 roku w kolekcji Muzeum Sztuki w Łodzi, zakupiony został od Bolesława Hochlingera (przyjaciela Strzemińskiego). Ma kształt horyzontalnego prostokąta, wymiary $30 \times 42 \mathrm{~cm}$. Jego lektura możliwa jest przynajmniej z dwóch perspektyw: jako przedstawienia oglądanego od frontu i reprezentacji widzianej z góry. Czytane od frontu, centrum kompozycji umieszczone zostało lekko przesunięte w lewo od głównej osi przedstawienia. To dwie konturowo określone formy, trzy mniejsze kształty umieszczone u dołu oraz towarzyszące im konstelacje kolistych plam - odbitych, grafitowych śladów palców. 
Dwie większe konturowe formy nie stykają się ze sobą, choć umieszczone są blisko siebie. Mniejsza przypomina dziecko uchwycone w geście podawania ręki dorosłemu. Ten wyraz strachu czy też potrzeby opieki i wsparcia, współ-bycia, jest szczególnie poruszający. Większa, dużo bardziej amorficzna, rozpływająca się w części szczytowej figura jest otwarta, nie odpowiada na gest dziecka. Jedynym szczegółem, który wskazuje, że to jest człowiek - są zniekształcone nogi. Dzięki ich usytuowaniu, a także wysuniętej w prawo szczególnie rozbudowanej, poruszonej partii środkowej, forma uzyskuje sugestię ruchu ku stronie prawej. Grafitowe ślady palców podkreślają transparentność form, a zarazem ich zabrudzenie. Mamy wrażenie jakby zakłóconego pola widoczności, pyłu gryzącego w oczy.

Jako odnoszące się do Zagłady Żydów rozpatrywał te rysunki Julian Przyboś, przyjaciel artysty. W tekście z 1956 roku Przyboś podejmuje wątek Zagłady w twórczości Strzemińskiego, myląc jednak cykl Deportacje z Tanie jak błoto (być może nakładając dodatkowo na swoją pomyłkę wspomnienie cyklu Moim przyjaciołom Żydom): „Są to obrazy abstrakcyjne a przedstawiające, zrobione najogólniejszą syntetyczną linią i kolorem, a dają przedmiotom wyraz szczególny, niepowtarzalny. Na przykład rysunki z cyklu Deportacje, obrazujące tragedię getta, lub cykl rysunków Ruiny. Jedną falistą linią określającą kontur, linią, zdawałoby się w poszczególnych rysunkach podobną, potrafił artysta dać swoim figurom ludzkim (bez zaznaczania oczu, ust i rysów) wstrząsający wyraz. Rysunki te wystawione tuż po wojnie w Łodzi zrobiły na mnie wrażenie silniejsze - dlaczegóż miałbym tego nie powiedzieć? - niż Guernica Picassa"48. Być może taką linię odczytania usłyszał Przyboś od swojego przyjaciela - Strzemińskiego. Chciałabym ją nieco rozwinąć i skomplikować.

W przypadku rysunku z 1943 roku oraz prac o rok późniejszych Strzemiński mógł opracowywać sceny, których był nie tylko naocznym, ale również audialnym czy wręcz „polisensorycznym” obserwatorem. Między połową stycznia a końcem lipca 1942 roku Niemcy wywieźli z łódzkiego getta do ośrodka zagłady w Chełmnie nad Nerem około 55000 Żydów. Wszystkich uśmiercono. Wcześniej, w styczniu 1942 roku naziści zlikwidowali obóz cygański, mordując 4300 Romów i Sinti również w Chełmnie nad Nerem ${ }^{49}$. Na

48 J. Przyboś Przedmowa..., w: W. Strzemiński Teoria widzenia, s. 8. Przyboś wątek ten kontynuuje w tekście Realizm rytmu fizjologicznego, w: Linia i gwar, Kraków 1959, s. 143.

49 S.M. Nowinowski, A. Sitarek, M. Trębacz, E. Wiatr Zarys historii getta łódzkiego, w: Getto łódzkie/ Litzmannstadtghetto, red. J. Baranowski, S.M. Nowinowski, Instytut Pamięci Narodowej Oddział w Łodzi, Łódź 2009, s. 30. 
początku maja 1944 roku Himmler zdecydował o likwidacji Litzmannstadtghetto $^{50}$. Między 23 czerwca a końcem sierpnia wywieziono ponad 70000 osób, początkowo do ośrodka zagłady w Chełmnie nad Nerem, a następnie do Auschwitz-Birkenau ${ }^{51}$. Być może te wydarzenia, jak również panujące w getcie ekstremalne warunki życia, skrajny głód, choroby i terror, mogły być punktem odniesienia dla rysunków Tanie jak błoto. Uderzająca jest jednak w tym cyklu dominująca obecność postaci małego dziecka. Znajduje się ona aż na siedmiu z jedenastu rysunków, które ściśle można powiązać z cyklem. Skłaniam się ku temu, by rysunki, na których obecne są postaci dzieci, zwłaszcza dwa, odnieść przede wszystkim do tragicznych wydarzeń Wielkiej Szpery z września 1942 roku. To właśnie wtedy z getta do Chełmna nad Nerem wywieziono i zamordowano dzieci poniżej 10 roku życia, osoby starsze powyżej 65 roku życia, ludzi słabych i chorych, łącznie 15681 osób ${ }^{52}$. Szperze towarzyszyły mordy i egzekucje, getto rozbrzmiewało płaczem, krzykiem i przerażeniem. Początkowo służba porządkowa, a następnie oddziały niemieckiej policji przeszukiwały getto kwartał po kwartale. Selekcji dokonywano często w sposób arbitralny. Zrozpaczeni ludzie usiłowali ukrywać dzieci, jednak ich sprzeciw spotykał się ze skrajnym okrucieństwem gestapo. Dzieci mordowano na oczach rodziców, rodziców na oczach dzieci. Niemcy zabili wówczas kilkadziesiąt lub kilkaset osób stawiających opór. Nie było osoby w getcie, która nie straciłaby kogoś bliskiego. Zdawano sobie również sprawę, że ofiary Szpery czeka pewna śmierć ${ }^{53}$. „Judel Kleiman”, pisze Andrea Löw w monografii łódzkiego getta, „był kierowcą jednego z samochodów i wspominał, że niektóre dzieci podczas jazdy śpiewały. Inne próbowały uciekać zeskakując z ciężarówek; rozstrzeliwano je na miejscu. To samo działo się z wybranymi do deportacji starszymi ludźmi, którzy usiłowali uciekać, a także z rodzicami próbującymi wydostać dzieci z samochodów. Podczas selekcji niemieccy policjanci zastrzelili kilka matek z dziećmi, gdy podjęły próbę ucieczki z podwórza obstawionej kamienicy"54.

50 Tamże, s. 38 .

51 J. Podolska Litzmannstadt Getto, http://www.lodzgetto.pl/litzmannstadt_getto_w_datach. html,2-42 (29.05.2017).

52 Tamże.

53 A. Löw Gettołódzkie/Litzmannstadt getto: warunkiżycia i sposoby przetrwania, przeł. M. Półrola, Ł. M. Plęs, Wydawnictwo Uniwersytetu Łódzkiego, Łódź 2012, s. 231-242. zob. również S.M. Nowinowski, A. Sitarek, M. Trębacz, E. Wiatr Zarys historii getta łódzkiego, s. 32-33. 
Postać dziecka w Tanie jak błoto reprezentowana jest jako trzy podstawowe figury, w dwóch przypadkach samotnie (to samo ujęcie, w drugim przypadku różni się wyłącznie dodaniem śladów zabrudzeń palców), w pięciu pozostałych obok figury dorosłego (trzy z nich to ten sam układ formalny, przedstawienia różnią się między sobą formatem i dodaniem odcisków palców oraz grubością linii). Jeśli spojrzymy na formy z góry, zobaczymy w nich nie kształty ludzkie, ale raczej resztki po człowieku: strużkę krwi, kształt odbity w miękkim, błotnistym podłożu. Przez zastosowanie równocześnie dwóch perspektyw - na wprost i z góry, dziecko we wspomnianych rysunkach ukazywane jest jako jeszcze żywe i już martwe, na granicy życia i śmierci. W sytuacji liminalnej ktoś mu towarzyszy (przedstawienie w parze lub obok figury dorosłego) lub umiera zupełnie samotne.

Zabrudzenia, ślady palców w czterech rysunkach cyklu Tanie jak błoto nie nadają przedmiotom objętości ani nie budują perspektywy, tak jak testował to Strzemiński w studiach martwych natur z 1943 roku. Obserwator patrzy na scenę, która dzieje się obok, dzieli go od niej dystans, ale w niej uczestniczy. Rysunki cyklu Tanie jak błoto zabrudzone odciskami palców to ekspozycja zatracenia granicy z przedstawieniem, podmiotu z przedmiotem, obserwowanego z obserwowanym. Te rysunki zaświadczają nie tylko wydarzeniom, ale również procesowi stopniowej dezintegracji. By użyć określenia Ewy Domańskiej są ekspresją „transhumanacji” podmiotu ${ }^{55}$, który w pewnym momencie niejako identyfikuje się ze sceną przedstawienia, a zarazem dokonuje „przeczłowieczenia”. Ukazane resztki po człowieku to ślady wdeptanego w błoto istnienia, dowody zbrukanego zbrodnią człowieczeństwa. Ślady palców natomiast są dowodem życia, którego wartość w obliczu dokonującej się katastrofy została zrównana z błotem. Zarazem palce dotykają śladu po człowieku w sposób niesłychanie czuły, bliski. Można powiedzieć, że to namiastka czynności żałobnej, symbolicznego grzebania umarłych. W cyklu Tanie jak błoto zespolenie obserwującego z obserwowanym następuje niemal literalnie. Strzemiński nie tylko wpisuje w rysunki swoją afektywną reakcję, zaangażowanie w obserwowaną rzeczywistość, drgnienie serca, ale również własną dezintegrację jako podmiot.

E. Domańska Hermeneutyka przejścia (Wspomnienia z Rosji Jana Żarno), w: tejże Historie niekonwencjonalne. Refleksja o przeszłości w nowej humanistyce, Wydawnictwo Poznańskie, Poznań 2006, s. 131-160. Ewa Domańska analizuje przeczłowieczenie "człowieka cywilizowanego" W "więźnia gułagu”, potwora na podstawie dziennika Jana Żarno i zawartej tam "opowieści niesamowitej" o kobiecie-kanibalu, która jej zdaniem jest "egzystencjalnym śladem" liminalnej kondycji samego autora. W tekście zob. s. 142-144. 


\section{Rysunki. Analiza neuroestetyczna ${ }^{56}$}

Linia stosowana przez Strzemińskiego w swoim zawieszeniu pomiędzy abstrakcją a realizmem pobudza do wolnych asocjacji, pełni rolę jak gdyby testu Rorschacha. Dzieje się tak, ponieważ rysunki Strzemińskiego wykorzystują m.in. opisane przez Vilayanura S. Ramachandrana i Williama Hirsteina prawo "przesunięcia szczytowego", tzn. wyodrębniają zasadnicze cechy obiektu, radykalizują kształty elementarne, wyłaniają reprezentację anatomicznych postaw ${ }^{57}$. Układ linii charakteryzujący się łagodnymi załamaniami, obłość kształtów kojarząca się z budową komórki, zaznaczenie postawy stojącej, nóg, porównania niższe/wyższe powodują, że rozpoznajemy jako widzowie najpierw figurę ludzką, a następnie dorosłego lub dziecko, kobietę lub mężczyznę, postawę np. rezygnacji, smutku czy wzburzenia. Strzemiński stosuje również prawo określane przez Ramachandrana i Hirsteina jako "grupowanie percepcyjne": wiąże kształty na zasadzie korelacji (wszystkie wykonane są wijącą się, ruchliwą kreską), co powoduje pracę poszczególnych modułów widzenia, segmentację pola widzenia, a w końcu osiągnięcie spójności i wyróżnienie (a także odróżnienie) poszczególnych figur. Angażuje również kontrast: białe-czarne, kontur-powierzchnia, wertykalne-horyzontalne, dekoracyjne-ascetyczne, a na poziomie metaforycznym żywe-martwe. Kontrast, jak piszą autorzy koncepcji neuroestetyki, szczególnie pobudza szlaki widzenia: „komórki umiejscowione w siatkówce oka, w ciele kolankowatym bocznym [...] i w obszarach kory odpowiedzialnych za widzenie reagują głównie na krawędzie [...]. Zatem narysowana linia lub karykatura pobudzają komórki tak efektywnie, jak potrafi to zrobić «czarno-biała» fotografia"58. Rysunki Strzemińskiego przypominają nieco wizualne układanki, gdzie jednak efekt końcowy nie jest zdeterminowamy. Układ wzrokowy zmuszany jest do poszukiwania rozwiązań, co Ramachandran i Hirstein określają jako prawo

56 W tekście proponuję analizę rysunków z perspektywy neuroestetycznej, która jednak jest w przypadku rysunków wojennych Strzemińskiego zasadniczo różna od spojrzenia proponowanego przez Łukasza Kędziorę, prezentowanego w książce Ł. Kędziory Wizualność dzieła sztuki...

57 V.S. Ramachandran, W. Hirstein Nauka wobec zagadnienia sztuki. Neurologiczna teoria doświadczenia estetycznego, przeł. M.B. Florek, P. Przybysz, "Studia z kognitywistyki i filozofii umysłu” $2006 \mathrm{nr}$ 2, s. 327-364. Zdaję sobie sprawę z pozornego anachronizmu tego ujęcia w odniesieniu do Strzemińskiego. Jednak opisywane przez autorów mechanizmy neurofizjologiczne w empirycznej praktyce artystów znane były od stuleci. Na temat „przesunięcia szczytowego” zob. s. 333-339.

58 Tamże, s. 348-349. 
"rozwiązywania problemów za pomocą percepcji"59. Prymarne formy, ich grupowanie, a także kontrast umożliwiający oddzielenie figury od tła bazują bowiem na pobudzeniu układu nerwowego związanego z widzeniem. Wraz z nim, jak twierdzą Ramachandran i Hirstein, uruchamia się proces percepcyjny, a także układ limbiczny odpowiedzialny m.in. za afekty i emocje. Zatem rysunki te są nie tylko świadectwem rzeczywistych zdarzeń, a zarazem zapisem afektywnej reakcji artysty, ale również każdorazowo uaktywniają różnorodne ośrodki mózgu widza. Jako proponowane przeze mnie neuroświadectwo zmuszają do zaangażowania uwagi, a wraz z nią do reakcji emocjonalnej oraz procesów świadomych związanych z pamięcią i rozumieniem, zarówno po stronie artysty, jak i odbiorcy.

We współczesnych ujęciach neurologicznych wprost mówi się o "mózgu wzrokowym”. Semir Zeki twierdzi, że „by zdobyć wiedzę o tym, co jest przedmiotem widzenia, mózg musi nie tylko analizować obraz prezentowany na siatkówce, lecz także aktywnie konstruować świat widzialny. [...] Nie jest już możliwe oddzielenie procesu widzenia od rozumienia. [...] W istocie świadomość jest własnością złożonych neuronalnych mechanizmów, które rozwinęły się w mózgu dla zdobycia wiedzy"60. Strzemiński posiadał niezwykle nowoczesny pogląd na temat powiązania pracy mózgu z aparatem wzrokowym. Nieco analogicznie do cytowanego Semira Zekiego, choć oczywiście używając zupełnie innej terminologii i kierując się raczej doświadczeniami artystycznymi, twierdził, że to właśnie myśl stawia pytania, na które odpowiada oko. Widzenie zaś jest nieustannym procesem pracy i wymiany między okiem i mózgiem. Tak pojęte widzenie to świadomość wzrokowa, aktywność widzenia, rozumienia i wytwarzania wiedzy. To pulsujące i drżące ciało, zapętlone z umysłem, którego emanacją jest obserwujące świat oko zbliża nas do człowieczeństwa ${ }^{61}$.

Neuroświadectwo Strzemińskiego to wyłaniające się obrazy zakładające nie tylko aktywny proces widzenia, ale również rozumienia zapoczątkowany jednak na poziomie nieświadomym, neurologicznym. W rysunkach wojennych po raz pierwszy sprzężony proces widzenia odbywający się między narządem wzroku i mózgiem pozwala na wyłonienie z rysunków figur, obiektów i scen odnoszących się do świata przedmiotowego, które nabierają życia

Tamże, s. 361.

W. Strzemiński Teoria widzenia, passim. 
i ruchu w momencie ich spostrzeżenia, umożliwiając rozpoznanie rozbłyskującej, bolesnej historii. Strzemiński budował swoją wzrokową świadomość usiłując ochronić resztki (swego) człowieczeństwa. Jej wynikiem były prace, które określam jako neuroświadectwo ${ }^{62}$. Ten wizualny zapis przekraczających fantazmaty wydarzeń granicznych, a zarazem ich efektów odciskających się w ucieleśnionej podmiotowości i powracających jak echo w reprezentacji to podstawa najważniejszej pracy teoretycznej określającej nowoczesność w Polsce - Teorii widzenia. Zręby jej najważniejszych pojęć teoretycznych i kategorii, tak istotnych dla artystów polskiej neoawangardy, zostały określone przez nieheroicznego obserwatora, w cieniu rozpadającego się świata.

62 Pojęcie neuroświadectwa, na co zwróciła mi uwagę Ewa Domańska, istnieje już w neuropsychiatrii, psychiatrii sądowej, łączy się ze zwrotem kryminalistycznym i w tym kierunku zamierzam tę kategorię rozwijać. 


\section{Abstract}

\section{Luiza Nader}

ACADEMY OF FINE ARTS IN WARSAW

Strzemiński's War

Nader treats selected cycles from Władysław Strzemiński's so-called "war drawings" (1939-1944) as a particular mode of visual testimony where a liminal experience is constructed from an observer's position. Nader reads the drawings as an "abstract" or "universal" idiom. Her interpretation is based on Strzemiński's "empirical method" as outlined in his The Theory of Sight. She examines the autobiographical and referential value of the works discussed, exploring each cycle of drawings with reference to the artist's experience and understanding, as well as the particular framework of wartime events that Strzemiński witnessed - deportations under the Soviet Occupation of the Eastern Borderlands, the resettlement of the Polish population of Litzmannstadt and the mass murder of Jews. Using both historical and neuroaesthetical frameworks (based on the work of Vilayanur S. Ramachandran and William Hirstein), Nader proposes to describe Strzemiński's wartime drawings in terms of neurotestimony: a visual image that supposes not only an active process of seeing but also a process of understanding that must begin on the level of the body's neurological phenomena.

\section{Keywords}

Władysław Strzemiński, war, Shoah, neuroaesthetics, neurotestimony 